RAD Conference Proceedings, vol. 2, pp. 1-5, 2017

www.rad-proceedings.org

\title{
THE ASSESSMENT OF CYTOGENETIC INDICES OF CHERNOBYL POWER PLANT DISASTER LIQUIDATORS
}

\author{
N.M. Hovhannisyan ${ }^{*}$, A.G. Karapetyan'1, V.S. Grigoryan² \\ ${ }^{1}$ Scientific Center of Radiation Medicine and Burns, Yerevan, Armenia \\ ${ }^{2}$ Yerevan State Medical University, Yerevan, Armenia
}

\begin{abstract}
The aim of the current research was to detect and assess the cytogenetic disorders of disaster fighters of Chernobyl nuclear power plant catastrophe, depending on radiation and non-radiation factors in the early and distant post-disaster periods with the help of system analysis methods. One can come across works dedicated to the study of genetic disorders of organisms exposed to a high level of radiation, but there are not enough data about the changes in these indices in case of low level radiation (lower than $1 \mathrm{~Gy}$ ). This is the reason why it is of interest to find out the role of cytogenetic indices in the development of radiobiological effects in case of low dosage exposure. The results of regression, factorial dispersive multi regression and discriminant analyses methods of cytogenetic indices are presented in the study.
\end{abstract}

Key words: Chromatid changes, chromosome aberrations, ionizing radiation, proliferative activity, radiation and age factors

DOI: $10.21175 / \operatorname{RadProc} .2017 .01$

\section{INTRODUCTION}

It is known that the damage to the deoxyribonucleic acid (DNA) is the principal initiating event after the radiation of the organism which serves the basis for considering the destabilization of chromosomes as one of the first and direct indicators of Ionizing Radiation impact on the cell [1], [2]. Radiation-initiated genome instability appears and practically all the main distant consequences of ionizing radiation - mutagenesis, carcinogenesis, ageing - are connected to it [3]-[5].

Genome instability is an important factor for the biological indication of the radial damage in the early post-disaster period as well as for the prediction of the development of distant negative effects of the ionizing radiation influence. Chromosome aberrations and the appearance of gene mutations indicate the possibility of damage to the organism which will be discovered in future.

At present, the classical chromosome analysis of human blood lymphocytes is one of the available and widely used methods of the chromosome instability assessment of the radiation-exposed human population [6], [7]. The character of structural reconstruction and frequency depend on the type of ionizing radiation [8], [9].

\section{MATERIALS AND METHODS}

The data of 30 years of observations on the condition of the chromosomal apparatus of the somatic cells (peripheral blood lymphocytes) of the liquidators are analyzed in the present study (350 liquidators whose average age is $63.05 \pm 5.2$ have been examined and over 55000 metaphases have been analyzed).

The cytogenetic examination included chromosome analysis by means of Giemsa staining recommended by the International Atomic Energy Agency (IAEA) [10], with a few modifications used in the laboratory of cytogenetics in the Centre of Radiation Medicine and Burns of the RA, which are connected with the assessment of the mitotic index (the quantity of mitosis on 1000 cells). The stimulation of lymphocytes to division (blood lymphocytes are in an interphase stage) has its own individual fluctuations which can depend on the condition of the organism (a disease or the impact of external factors). This is the reason why the quantity of metaphases for $0.5 \mathrm{ml}$ of cultural suspension received after processing $1.2 \mathrm{ml}$ of whole blood was taken per unit of proliferative activity of phytohemagglutinin-stimulated lymphocytes (only plates in the stage of cell division metaphase were taken for tests; helix formation chromosome level was not less than 20\%).

Statistical processing of the numerical materials was carried out with the help of regression, factorial

*ncrmio@web.am 
dispersive, multi regression and discriminant analyses methods. Computer programs for statistical processing of numerical figure arrays were used: the electronic worksheet Microsoft Excel and specialized statistical data Statsoft, SPSS-6 and StatGraphics Plus [11], [12].

\section{RESUlTS AND DISCUSSION}

The research that has been carried out has shown that the peripheral blood lymphocyte chromosomes have been considerably damaged (Table 1 ). It should be noted that these changes also depend on the time that has passed after radiation (remoteness of the occurrence). All the figures shown in the table have changed significantly by the end of the research. Starting from 1987, the level of chromosome aberrations was 2.5 times higher than the spontaneous level. This index was $5.94 \pm 1.01$ in the middle post disaster period and the average number of chromosome aberrations reached $14.92 \pm 1.37$ in the distant period. The level of chromosome aberrations in the liquidators was significantly higher than the control values until the end of the research.

Table 1. The change of results over time

\begin{tabular}{|c|c|c|c|c|}
\hline Indices & Control & Early period & $\begin{array}{l}\text { Middle } \\
\text { period }\end{array}$ & $\begin{array}{l}\text { Distant } \\
\text { period }\end{array}$ \\
\hline $\begin{array}{l}\text { Chromosome } \\
\text { aberrations by } \\
100 \text { cells }\end{array}$ & $\begin{array}{c}1.27 \\
\pm 0.39 \\
\end{array}$ & $\begin{array}{c}3.58 \pm 0.34 \\
(p<0.001) \\
\end{array}$ & $\begin{array}{l}5.94 \pm 1.01 \\
(\mathrm{p}<0.001)\end{array}$ & $\begin{array}{c}14.92 \pm 1.37 \\
(\mathrm{p}<0.001)\end{array}$ \\
\hline $\begin{array}{l}\text { Polyploid cells } \\
\text { (4n) by } 100 \\
\text { metaphases } \\
\end{array}$ & $\begin{array}{c}0.059 \\
\pm 0.035 \\
\end{array}$ & $\begin{array}{c}0.13 \pm 0.01 \\
(\mathrm{p}<0.05)\end{array}$ & $\begin{array}{c}0.82 \pm 0.24 \\
(p<0.002)\end{array}$ & $\begin{array}{c}0.73 \pm 0.31 \\
(\mathrm{p}<0.05)\end{array}$ \\
\hline $\begin{array}{l}\text { Chromatid } \\
\text { changes } \\
\text { (single DNA } \\
\text { breaks) } \\
\end{array}$ & 0 & $2.29 \pm 0.21$ & $3.24 \pm 0.61$ & $7.69 \pm 2.11$ \\
\hline $\begin{array}{l}\text { Chromosome } \\
\text { changes } \\
\text { (double DNA } \\
\text { breaks) }\end{array}$ & 0 & $1.31 \pm 0.19$ & $2.6 \pm 0.73$ & $5.76 \pm 1.27$ \\
\hline $\begin{array}{l}\text { Proliferative } \\
\text { activity } \\
\text { (quantity of } \\
\text { metaphases) } \\
\text { by } 1.2 \mathrm{ml} \text { of } \\
\text { blood }\end{array}$ & $\begin{array}{l}290.81 \\
\pm 24.56\end{array}$ & - & $\begin{array}{l}248.3 \\
\pm 28.8\end{array}$ & $\begin{array}{c}176.08 \\
\pm 49.27 \\
(\mathrm{p}<0.05)\end{array}$ \\
\hline
\end{tabular}

We found out that in the case of statistical analysis of the data of chromosome aberrations, the most suitable model out of those used at present is the logarithmic one [12] to describe the change dynamics of this index level. We have got the coefficients for the equation of the logarithmic regression of chromosome aberration change: $y=0.159+9.605 \lg (x)$, where $x$ is the time interval (the number of years after the disaster), and $\mathrm{y}$ is the level of chromosome aberrations. This formula makes it possible not only to obtain the prognosis in case of extrapolation, but through interpolation to get the theoretical part of the graph characterizing the level of chromosome aberrations for those years when no observations were carried out as well.

In terms of aberration types, mainly chromatid and chromosome aberrations have been registered (single and double DNA breaks) and starting from 1995, only exchange aberrations have been observed. The dynamics of the chromatid changes was described by the graph of exponential regression and our formula describing this dynamics: $y=1.8441 \mathrm{e}^{0.0736 \mathrm{x}}$, where $\mathrm{x}$ is the number of years after the disaster and $y$ is the average number of single DNA breaks, which reached $7.69 \pm 2.11$ in the distant period.

The double breaks of the DNA are no less informative indices. The dynamics of the number of double breaks can be described by the formula $\mathrm{y}=1.5524 \mathrm{e}^{(0.0565 \mathrm{x})}$, where $\mathrm{x}$ is the number of years after Chernobyl nuclear power plant catastrophe and y is the number of double breaks, which by the end of the research was $5.76 \pm 1.27$.

The equations obtained through the 3 abovementioned indices make it possible to predict quite precisely the increase of these indices in the future years (95\% confidence level of the regression graph embraces $90-95 \%$ of the empirical value of this index).

We have also tried to find out the multiregression connection and its change between the number of single (X) and double (Y) breaks and the level of chromosome aberrations (Z) in the early and distant observation periods (Figure 1).

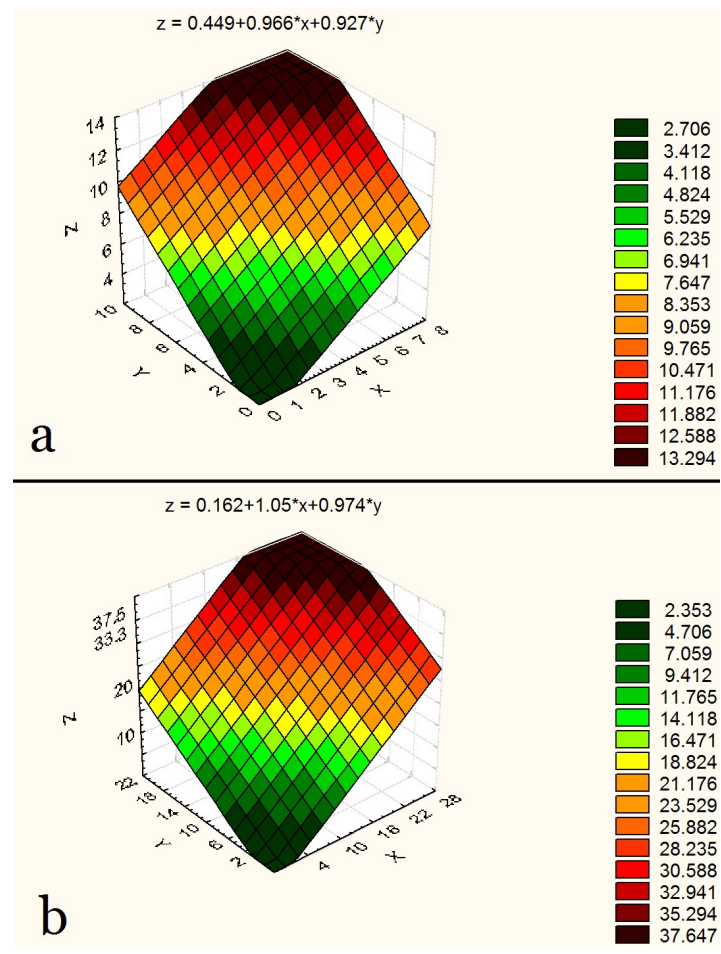

Figure 1. The multiregression dependence between the number of single and double breaks and the level of chromosome aberrations in the early (a) and distant (b) post disaster periods. $\mathrm{X}$ - the number of single breaks, $\mathrm{Y}$ - the number of double breaks, $\mathrm{Z}$ - the level of chromosome aberrations

It was found out that the increase in the number of breaks is in correlation with the increase in the level of chromosome aberrations, and that is why, in spite of their increase throughout 30 years, their correlation undergoes insignificant changes (a decrease in the free coefficient by 2.77 times was observed in the distant period relative to the early period). 
The increase in the exchange aberrations (of marker chromosomes) is one of the possible mechanisms of elimination of genetic disorders in the cell which does not go through the next mitosis and the result is that daughter cells are not formed, i.e. chromosome aberrations are eliminated [13].

Dicentrics and rings that are considered the biomarkers of ionizing radiation were not discovered in the liquidators. This is accounted for by two reasons:

1) the cells with the mentioned biomarkers were quickly eliminated (while the research started a year after the radiation),

2) the liquidators have got doses lower than $1 \mathrm{~Gy}$ (a group of authors [14], [15] think that dicentrics and rings are formed in case of over 1-1.5 Gy radiation dose)

A very important point in the observations was the discovery of poyploid cells (mainly tetraploid). In the research until 1990, polyploid forms of lymphocytes were registered sporadically. Later on, a significant increase in the number of polyploid cells was registered.

From the point of view of genome instability, realignments of chromatin are estimated as adaptation process with the aim of eliminating the genetic disorders in the cell and the change in ploidy is one of the possible mechanisms.

The detection of ploidy change of the cells in the liquidators is of wavelike character; however, a clear tendency towards the increase of this index is noticeable. The theoretical curve (exponential regression) describing the dynamics of the change of polyploidy cell number is shown as follows: $\mathrm{y}=0.2325 \mathrm{e}^{0.0607 \mathrm{x}}$ where $\mathrm{x}$ is the number of years after the disaster and $y$ is the number of polyploid cells.

The importance of the detection of the increase in polyploid cells should be noted as a possible cytogenetic marker in the radiated organism. There is no doubt that participation in the catastrophe liquidation work induced the remaining genome damage.

Despite the wavelike change in the proliferative activity, it is not difficult to notice the tendency to the decrease of this index by following the dynamics. This tendency can be described by the logarithmical regression curve $y=360.3823-134.4805 \lg (\mathrm{x})$, where $\mathrm{x}$ is the number of years after the disaster and $y$ is the level of proliferative activity of lectin-stimulated lymphocytes. This curve enables us to get the prognosis of the change in the proliferative activity of lectinstimulated lymphocytes for the next 5 years.

It is known that cytogenetic disorders become more frequent with the age, intensifying the changes in the chromosome apparatus of lymphocytes [16].

We made use of a statistical mathematical device which can detect and assess even an insignificant correlation of genetic damage with the doses of radiation received by the liquidators on the site of the catastrophe. We made use of factorial dispersive analysis to find out the impact of the radiation factor on the cytogenetic indices throughout the observation period and compare it to the age factor.

The factorial dispersive analysis of the cytogenetic indices has shown that the radiation factor was more significant for the indices chromosome aberrations and proliferative activity (Figure 2). The radiation factor impact share on the chromosome aberrations has two peaks occurring in 1992 and 2004 (93.28 \% and $91.75 \%$, respectively). A little decrease in this index was observed in the rest of the years. The impact of the age factor prevails over the radiation factor only by the end of the research. As for the decrease period of the radiation factor impact from 1994-2003, it is apparent that there were stronger factor impacts here on the number of the chromosome aberrations overlooked by us (this can be hard socio-economic conditions, smoking, the increase in the percentage of sickness rate, etc. Those factors seem to be the reason for the decrease in the impact shares of the radiation factor) [17].

As for the proliferative activity, the impact of both age and radiation factors is observed (Figure 2(b)). The interdependence of these 2 factors attracts attention, with the increase in the impact of the age factor (in 2003 , it was $56.52 \%$ ), the impact of the radiation factor decreases (19.24\%) and vice versa (in 2004, 35.36\% and $64.28 \%$, respectively).

In spite of the fact that a decrease in the radiation factor impact is observed in the distant period, the use of the modern statistical methods of system analysis [11], [12] makes it possible to assess and find out the indirect dose dependence of cytogenetic disorders even after 30 years.
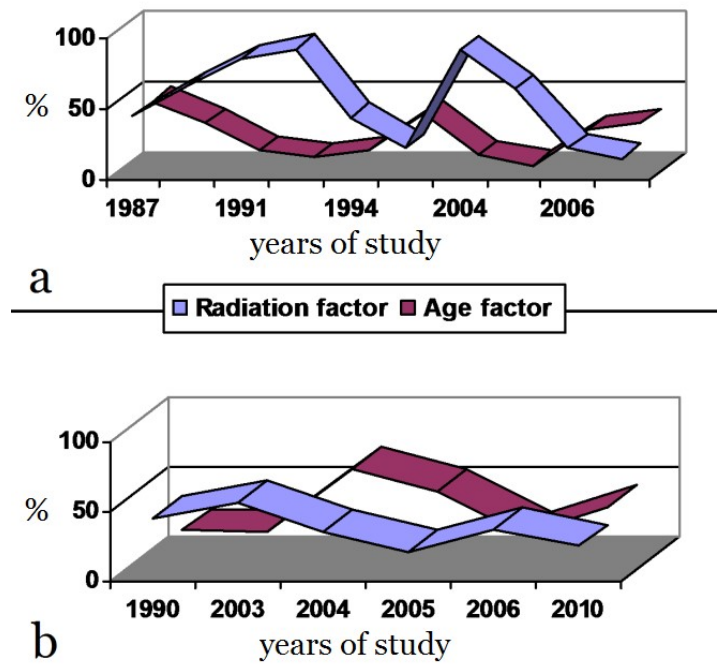

Figure 2. Change dynamics of the impact shares of the radiation factor and the age factor on the level of the chromosome aberrations (a) and the proliferative activity (b)

It is known that the parameter "year of stay" indicates indirectly the dose received by the liquidators. Relying on this fact we made a decision to use the discriminant analysis method (in order to classify), which enables us to receive the group arrangements of the liquidators who were on the disaster site from 1986, 1987 and 1988, on the basis of identification (Figure 3). 


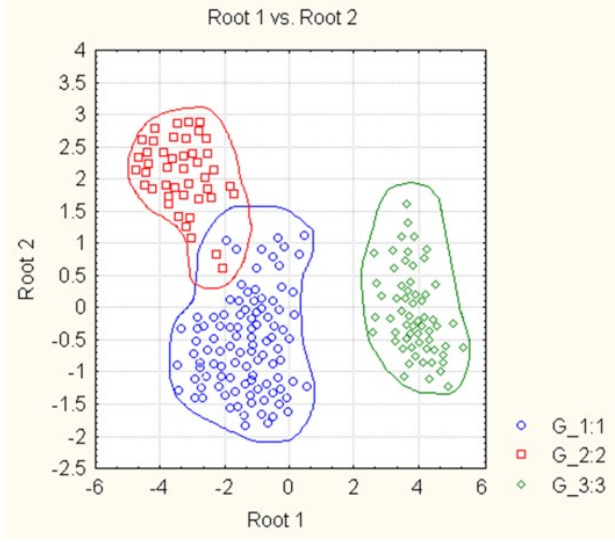

Figure 3. Classification of 206 liquidators in groups who arrived at the site in 1986, 1987 and 1988. Symbols: Root 1, 2 - 1st and 2nd roots of discrimination, G1, G2, G3 - groups of people who took part in the catastrophe liquidation in 1986, 1987,1988 , respectively

The results of the discriminant analysis of 206 examined liquidators are shown in Figure 3.

The predictors of the classification were 9 cytogenetic and immunological indices: chromosome aberrations, the number of polyploid cells, proliferative activity, the number of leucocytes, the number of lymphocytes, and the relative and absolute number of T- and B-lymphocytes. The analysis was supposed to show if it is possible to divide the liquidators on the basis of the time of their stay on the catastrophe site (separately into 1986, 1987, 1988) and classify them into groups. The indices of each liquidator are shown with a separate "dot" in Figure 3.

The graphs of the liquidators who were on the disaster site in different years are apart from one another, making a relatively distinguished, separate group in the domain of the discriminant functions. The results of the discriminant analysis testify that the liquidators who were in the disaster zone in different years, thereby getting different doses of radiation, are in different groups, having distinguishing features making the group. There is only an insignificant imposition of 2 groups of liquidators, who were on the disaster site in 1986 and 1987. This apparently happened, because 2-3 liquidators from the group were on the site at the end of 1986 and at the beginning of 1987 and were imposed to almost the same dose of radiation. The liquidators of 1988 clearly made a separate group. It shows that even after 30 years, chromosome aberrations and shifts in the immunological indices can testify dose dependence with the help of a mathematical device.

\section{CONCLUSIONS}

Summing up the results of cytogenetic examination of the Armenian liquidators, it can be stated that the instability of the lymphocyte genome of the peripheral blood is quite well expressed: these figures are significantly different from the control figures by the end of the research. An increase in the indices was observed: the chromosome aberrations by 100 cells, the polyploid cells by 100 metaphases, the number of single and double breaks of the DNA. The proliferative activity decreased and by the end of the research was 1.65 times smaller than the control.

The methods of the regression analysis made it possible not only to describe the change dynamics of these indices throughout many years, but also, by extrapolating, to get the prognosis for the future years with an acceptable exactness.

The cytogenetic analysis of the liquidators is directly linked to the definition of the concept of the distant consequences of ionizing radiation. Our research provides an assessment of radiation and nonradiation factor contributions to the observed changes. All this has a scientific practical significance in the establishment of the possible interconnection between genome instability and such distant consequences as mutagenenesis (increase in the congenital malformations, change of the reproduction function of the organism and condition of the genital glands, frequency of chromosome and hereditary diseases), cancerogenesis, ageing, etc.

\section{REFERENCES}

1. J. B. Little, "Genomic instability and radiation," Journal of Radiological Protection, vol. 23, no. 2, pp. 173-181, Jun. 2003.

DOI: $10.1088 / 0952-4746 / 23 / 2 / 304$

PMid: 12875549

2. K. Suzuki, M. Ojima, S. Kodama, M. Watanabe, "Radiation-induced DNA damage and delayed induced genomic instability," Oncogene, vol. 22, no. 45, pp. 6988-6993, Oct. 2003.

DOI: $10.1038 /$ sj.onc.1206881 PMid: 14557802

3. W. Han, K. N. Yu, "Ionizing Radiation, DNA Double Strand Break and Mutation," Advances in Genetics Research, vol. 4, pp. 1-13, Jan. 2010.

Retrieved from: https://www.researchgate.net/publication/266462167 Ionizing Radiation_DNA Double Strand Break an d Mutation

Retrieved on: Feb 2, 2017

4. E. S. Gilbert, "Ionizing Radiation and Cancer Risks," International Journal Radiation Biology, vol. 85, no. 6, pp. 467-482, Jun. 2009.

DOI: $10.1080 / 09553000902883836$

PMid: 19401906

PMCid: PMC2859619

5. R. B. Richardson, "Ionizing radiation and aging: rejuvenating an old idea," Aging (Albany NY), vol. 1, no. 11, pp.887-902, Nov. 2009.

DOI: $10.18632 /$ aging. 100081

PMid: 20157573 PMCid: PMC2815743

6. M. Nakano, Y. Kodama, K. Ohtaki, M. Itoh, R. Delongchamp, A. Awa et al., "Detection of stable chromosome aberrations by FISH in A-bomb survivors: Comparison with previous solid Giemsa staining data on the same 230 individuals," Int. J. Radiation Biology, vol. 77, no. 9, pp.971-977, Sep. 2001. DOI: $10.1080 / 09553000110050065$ PMid: 11576457

7. K. Breger, L. Smith, M. Turker, M. Trayer, "Ionizing radiation induces frequent translocations with delayed replication and condensation," Cancer Res., vol. 64, no. 22, pp.8231-8238, Nov. 2004. DOI: 10.1158/0008-5472.CAN-04-0879 PMid: 15548689

8. B. R. Scott, K. M. Gott, C. A. Potter, J. Wilder, "A Comparison of in vivo cellular responses to Cs-137 
Gamma Rays and 320-Kv X-rays,” Dose Response, vol. 11, no. 4, pp. 459-474, Nov. 2013

DOI: $10.2203 /$ dose-response.12-050.Scott

PMid: 24298223

PMCid: PMC3834739

9. Н. Д. Окладникова, Б. Р. Скотт, З. Б. Токарская,

Г. В. Жунтова, В.Ф. Хохряков, В.А. Сырчиков, Е.С. Григорьева, "Уровень нестабильных и стабильных хромосомных аберраций при инкорпорации нетранспортабельных соединений плутония-239," Медицинская радиология и радиационная безопасность, т. 50, № 6, с. 23-32, 2005. (N. D. Okladnikova, B. R. Scott, Z. B. Tokarskaya, G. V. Zhuntova, V.F. Khokhryakov, V.A. Syrchikov, E.S. Grigoryeva, "Evaluation of Genome Stability at Incorporation of Non-Transpose Compounds of Pu-239," Medical Radiology and Radiation Safety, vol. 50, no. 6, pp. 23-32, 2005.)

10. Cryptogenic Analysis for Radiation Dose Assessment, 1st ed., IAEA, Vienna, Austria, 2001, pp. 1-88. Retrieved from:

http://wwwpub.iaea.org/MTCD/publications/PDF/TRS405_scr.pd $\mathrm{f}$

Retrieved on: Jan. 24, 2017

11. В. П. Боровиков, "Классификация данных в системе STATISTICA - модуль Discriminant Analysis,” в Популярное введение в программу STATISTICA, 1-е издание, Москва, Россия: КомпьютерПресс, 1998, гл. 5, с. 163-185 (V. P. Borovikov, "Classification of data in Statistica system - Discriminant Analysis module," in Popular introduction to the program STATISTICA, 1st ed., Moscow, Russia: ComputerPress, 1998, ch. 5, pp. 163-185.)

12. Э.А. Вуколов, “Дисперсионный анализ," "Регрессионный анализ," в Основы статистического анализа, 2-е издание, Москва, Россия: Форум, 2008, гл. 5-6, с. 150-240. (E. A. Vukolov, "Dispersive analysis," "Regression analysis," in Fundamentals of statistical analysis, 2nd ed., Moscow, Russia: Forum, 2008, ch. 5-6, pp. 150-240.)
13. J. S. Bedford, D. Phil, "Sublethal damage, potentially lethal damage, and chromosomal aberrations in mammalian cells exposed to ionizing radiations," Int. J. Radiat. Oncol. Biol. Phys., vol. 21, no. 6, pp. 1457-1469, Nov. 1991.

DOI: 10.1016/0360-3016(91)90320-4

14. Н. Л. Шмакова, Е. А. Насонова, Е.А. Красавин, Л.А. Мельникова, Т.А. Фадеева, “Индукция хромосомных аберраций и микроядер в лимфоцитах периферической крови человека при действии малых доз облучения,” Радиационная биология. Радиоэкология, т. 46, № 4, с. 480-487, 2006. (N. L. Shmakova, E. A. Nasonova, E. A. Krasavin, L. A. Melnikova, T. A. Fadeeva, "Induction of Chromosome Aberrations and Micronuclei in Human Peripheral Blood Lymphocytes at Low Dose of Radiation," Radiation biology. Radioecology, vol. 46, no. 4, pp. 480-487, 2006.)

15. V. Yu. Kravtsov, R. F. Fedortseva, Ye. V. Starkova, N. M. Yartseva, A. M. Nikiforov, "Tailed nuclei and dicentric chromosomes in irradiated subjects," Appl. Radiat. Isot., vol. 52, no. 2, pp. 1121-1127, May 2000. PMCid: PMC3333048

16. V. Gorbunova, A. Seluanov, Z. Mao, C. Hine, "Changes in DNA repair during aging," Nucleic Acids Res. vol. 35 , no. 22, pp. 7466-7474, Dec. 2007.

DOI: $10.1093 / \mathrm{nar} / \mathrm{gkm} 756$

PMid: 17913742 PMCid: PMC2190694

17. S. M. Gollin, "Acquired chromosome abnormalities: the cytogenetics of cancer," in Encyclopedia of Genetics, Genomics, Proteomics and Bioinformatics, vol. 1, L. Jorde, P. Little, M. Dunn, S. Subramaniam, Eds., 1st ed., John Wiley and Sons, 2005, ch. 1, sec. 2, pp. 1-14.

DOI: 10.1002/047001153X.g102204 